\title{
The geological record of storm events over the last 1000 years in the Salerno Bay (Southern Tyrrhenian Sea): new proxy evidences
}

\author{
F. Budillon, E. Esposito, M. Iorio, N. Pelosi, S. Porfido, and C. Violante \\ Consiglio Nazionale delle Ricerche, Istituto per l'Ambiente Marino Costiero, Calata Porta di Massa, 80 - 80133 Napoli, Italy
}

Received: 19 November 2004 - Revised: 7 March 2005 - Accepted: 10 March 2005 - Published: 9 May 2005

\begin{abstract}
The shallow marine Late Holocene wedge of the northern Salerno Bay shelf (Southern Tyrrhenian Sea) discloses the presence of four decimetric shelf-tapering sand beds. Their internal features, depicted by cores analysis and their stratigraphic position, revealed by VHR seismic investigations, inferred sandy layers as being the result of flash deposition, storm controlled, thus episodic. Stratigraphic correlations among cores lead to constrain sandy layers deposition to storm events falling in the 11th, 16th, 19th and 20th centuries. A certain attribution of the most recent event bed to the major cloudburst that hit the Salerno region in 1954 A.D. and resulted in a disastrous flood of the Bonea stream, was formerly achieved. A tentative link with two sea-storms that occurred in the 1544 A.D. and in the 1879 A.D. and well documented by historical sources is here proposed to explain the deposition of the two previous event beds. The deposition of these sandy layers must be related to major storm events, since their preservation in the stratigraphic record is not common. Lithostratigraphic and textural differences between flood and sea-storm emplacement emerge from the study of sandy layers in cores and point to a prevalence of sea-storm deposits in the middle shelf compared to flood deposits. Seismic stratigraphic evidence lead us to suppose that the style of episodic flash deposition has been running on for the last 2-3 kyr and is probably linked to a climatic trend of the region.
\end{abstract}

\section{Introduction}

Sharp based sandy layers interlayered in muddy sequences of middle shelf environment are normally regarded as a proxy for past storminess. In fact, both down-welling currents originated by sea-storms (Myrow and Southard, 1996) and hyperpycnal flows, i.e. high density sediment charged underflow, generated at the river mouth by floods (Mulder and Syvit-

Correspondence to: F. Budillon

(francesca.budillon@iamc.cnr.it) ski, 1995) are dynamic erosional/depositional processes related to intense cyclonic circulation at the middle latitudes. Both processes are particularly effective in delivering huge amounts of sand to the infralittoral and circalittoral environment and settle sharp based sandy layers, with possibly very similar lithologic features. Most of the diagnostic elements for recognizing hyperpycnal flow deposits (HFD) come out from observations at the field scale of the inland geological record (Froese et al., 2003; Mutti et al., 2003). It is widely accepted that flood deposits are more widespread and therefore more accurately documented in the geological record than those in the modern shelf environment (Mutti et al., 2003; Geyer et al., 2004). Analogous considerations can be supported for sea-storm deposits (tempestites), which appear more consistent in the geological record (Dott and Bourgeois, 1982; Duke, 1985; Myrow and Southard, 1996) than in the modern shelves, where rarely more than $10 \mathrm{~cm}$ thick sand layers have been depicted (Morton, 1981; Niederoda et al., 1989; Snedden and Nummendal, 1991). The above indications, point to a practical difficulty in discriminating hyperpycnal flow from tempestite deposits on modern shelves by standard marine investigations (cores analysis and seismic surveying). In the Mediterranean area major sea-storms related to cyclonic circulation are often accompanied by cold fronts inducing heavy rainfall (Jansa, 2000; Ramos, 2000a, 2000b). Hyperpycnal flows at the mouth of flood-prone rivers can be triggered with a response of few hours especially in small sized catchments (Siccardi, 1996). In these cases both processes may couple in delivering and reworking sand in the littoral zone (Fan et al., 2004; Guillen et al., 2005).

The aim of this study is to provide practical diagnostic elements to distinguish the two depositional processes related to storm deposition by sediment core analysis and seismic surveying in shelf areas. A case study carried out off the Bonea stream mouth (Salerno Bay, Southern Tyrrhenian Sea, Fig. 1) is here presented; the use of several methodologies resulted in the chronologic constrain of the timing of storm related sandy layers deposition (Budillon et al., 2005); an attribution 


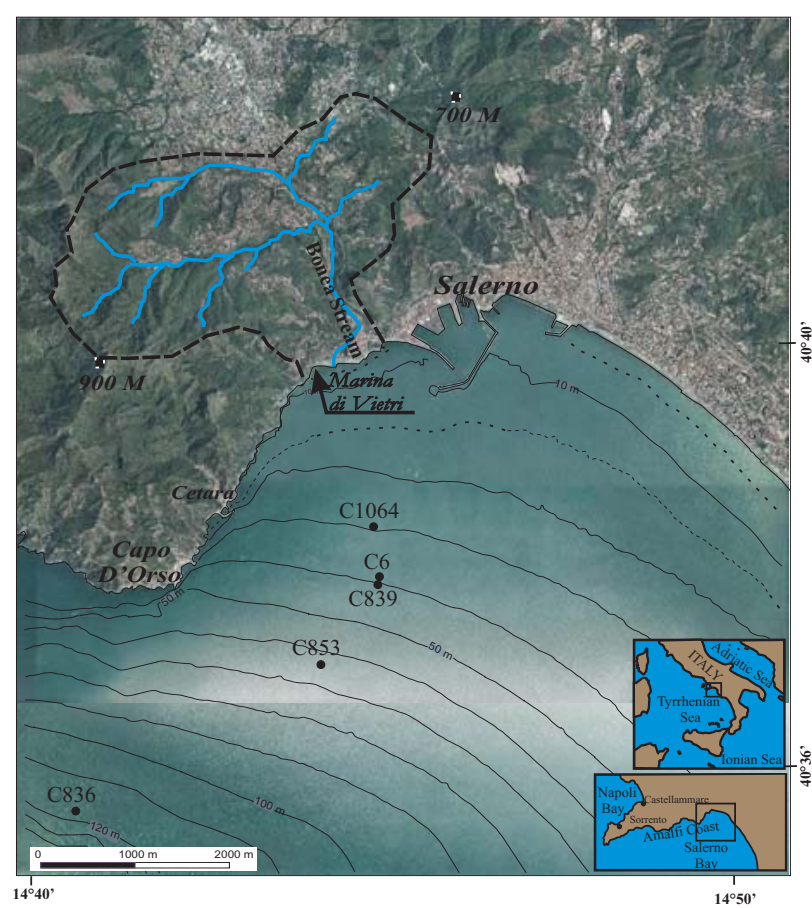

Fig. 1. Topography of the Salerno Bay shelf and coast and location of gravity cores. Dashed line bounds the Bonea stream catchments.

to storm events reported by historical sources is then here attempted.

\section{Geological setting}

The Bonea stream (Amalfi coast, Southern Apennines, Italy), flowing in the Salerno Bay (Fig. 1) has a drainage system extending over $22 \mathrm{~km}^{2}$ of a mountainous region of the Southern Apennines (Brancaccio et al., 1991). The high gradient of the Bonea fluvial path and the shortness of the transfer zone accounted for sediment charged flows moving rapidly downstream into the Salerno Bay during intense rainfalls (Esposito et al., 2004a). The fluvial regime of the Bonea Stream is typical of the Apennines, with low yields during Spring and Summer, and maximum capacity during Autumn and Winter, when seasonal rainfall reaches a peak and south-westerly cyclonic storms are more intense (Ramos, 2000a, 2000b). The Bonea stream flows in the Salerno Bay, which is characterised by a continental shelf about $9 \mathrm{~km}$ wide and is bounded seawards by a sharp shelf break at $120 \mathrm{~m}$ of depth (Fig. 1). Shelf gradient ranges between $0.6^{\circ}$ and $1^{\circ}$ and is accounted for by the geometry of the Late Holocene marine wedge. Well sorted sand, distinctive of the nearshore environment, spreads all along the northern coast of the Bay, down to $15 \mathrm{~m}$ of depth; deeper it gives way to less sorted muddy fine sand, typical of the inner shelf environment (Cocco et al., 1992).

The Salerno Bay is exposed to storms coming from N $190^{\circ}$ and $\mathrm{N} 280^{\circ}$ and the maximum fetch corresponds to the sub-sector $230^{\circ}-260^{\circ}(660 \mathrm{~nm})$ where the greatest number of wave-generating events originate. Storm waves approaching the coast from $\mathrm{N} 190^{\circ}-\mathrm{N} 220^{\circ}$ (about the $25 \%$ of the events) and from $\mathrm{N} 270^{\circ}-\mathrm{N} 280^{\circ}$ induce alongshore currents respectively towards NW and SE (Cocco et al., 1992).

\section{Methods and materials}

This study makes use of Very High Resolution (VHR) Sonar Chirp Lines, shot normally to the Bonea stream coast. Five gravity cores were used to gauge seismic facies. Grain size analysis was carried out on sandy layers found in cores every $5-10 \mathrm{~cm}$ with a spatial resolution of $3 \mathrm{~cm}$; sand was sieved through size classes of 500, 250, 125, 63 and 30 micron and weighted. Results were plotted on a modified Shepard (1954) diagram in order to point out the differences between hyperpycnal flow and tempestite deposit textures. Spectrophotometer measurements were taken with a Minolta Spectrophotometer CM 2002, and chromaticity parameter $\left(\mathrm{a}^{*}\right) \operatorname{logs}$ were added for three cores (C1064, C839, C853) to reinforce lithostratigraphic and magnetic susceptibilities correlation among cores (Budillon et al., 2005). The measurements were taken immediately after cores splitting in order to minimize redox-associated colour changes that occur when marine sediment is exposed to the atmosphere. A critical analysis of inventories, archival documents and literature was carried out in order to select major sea-storm events that hit the Salerno Bay over the last five centuries.

\section{Results}

\subsection{Inventories of sea-storms in the Salerno Bay area}

Based on the critical analysis of historical documents, ten major sea-storm events were recognized in the Salerno Bay between the 1544 and the 1900 A.D., among 35 events reported, and were classified as medium and heavy events (Table 1). The severity of these events was evaluated on the basis of several factors as the number of victims, the size of the coastal zone involved, damage on properties, harbour structures and littoral areas, and the number of times a single event is mentioned in archival documents. A widespread pattern of destruction characterized some of them, with numerous casualties, shipwrecks, loss of fleets, damage to harbours and coastal buildings. Among these events, the 1544, 1774 and 1879 A.D. sea-storms lead to a high number of deaths. The 1544 A.D. sea-storm has been widely reported because it caused the destruction of the fleet of the ill-famed Turkish pirate Khayr ad-Din, also known as "Red beard" (Camera, 1836). His whole fleet sunk in the proximity of Capo d'Orso (Fig. 1).

\subsection{Lithostratigraphy of cores and correlations}

The litho-stratigraphy of cores indicated four sharp based sandy layers in the muddy Late Holocene wedge (Fig. 2), thinning seaward. Correlations of sandy layers across cores 
Table 1. Major sea-storm events since the 16th century, deduced from: Archivio di Stato di Salerno (AS SA), Protocolli notarili, 1500-1798; Archivio di Stato di Salerno, (AS SA), Prefettura, 1879; Camera, M. (1836); Greco, M. (1709-1787).

\begin{tabular}{|c|c|c|c|c|}
\hline Date & Localities & Sea-storm induced effects & Sources & Note \\
\hline 1544.06 .27 & $\begin{array}{l}\text { Capo d'Orso, Amalfi Coast, } \\
\text { Salerno }\end{array}$ & $\begin{array}{l}\text { Destruction of the fleet of the Turkish } \\
\text { pirate Khayr ad-Din also known } \\
\text { as "Redbeard". }\end{array}$ & M. Camera, 1836 & Heavy \\
\hline 1597 & Amalfi Coast, Salerno Bay & $\begin{array}{l}\text { Damage to } 2 \text { buildings in Marina di Vietri, } \\
\text { destruction of } 2 \text { ships. }\end{array}$ & ASSA, Protocolli notarili, 1597 & Medium \\
\hline 1759.11.21 & Salerno & Damage to boats, 1 lost, 1 casualty. & M. Greco, $1709-1787$ & Medium \\
\hline 1770.04 .13 & Sorrento, Castellammare & One fallen boat, with 12 casulties. & M. Greco, 1709-1787 & Medium \\
\hline 1774.11 .25 & $\begin{array}{l}\text { Salerno, Vietri sul Mare, } \\
\text { Napoli Bay }\end{array}$ & $\begin{array}{l}2 \text { vessels lost in Salerno, } 4 \text { others damaged } \\
\text { in Vietri sul Mare and Naples. } \\
\text { Damage to the Naples harbour. }\end{array}$ & M. Greco, 1709-1787 & Heavy \\
\hline 1774.12 .03 & Salerno & & M. Greco, $1709-1787$ & Medium \\
\hline 1776.09.12 & Salerno, Vietri sul Mare. & & M. Greco, 1709-1787 & Medium \\
\hline 1778.01 .08 & Salerno & & M. Greco, $1709-1787$ & Medium \\
\hline 1781.11.24 & Salerno & 1 casualty. & M. Greco, 1709-1787 & Medium \\
\hline 1879.02 .25 & $\begin{array}{l}\text { Amalfi Coast, Vietri sul Mare, } \\
\text { Salerno }\end{array}$ & $\begin{array}{l}10 \text { vessels are lost, } 9 \text { casualties } \\
\text { in the Vietri offshore. }\end{array}$ & AS SA, Prefettura & Heavy \\
\hline
\end{tabular}
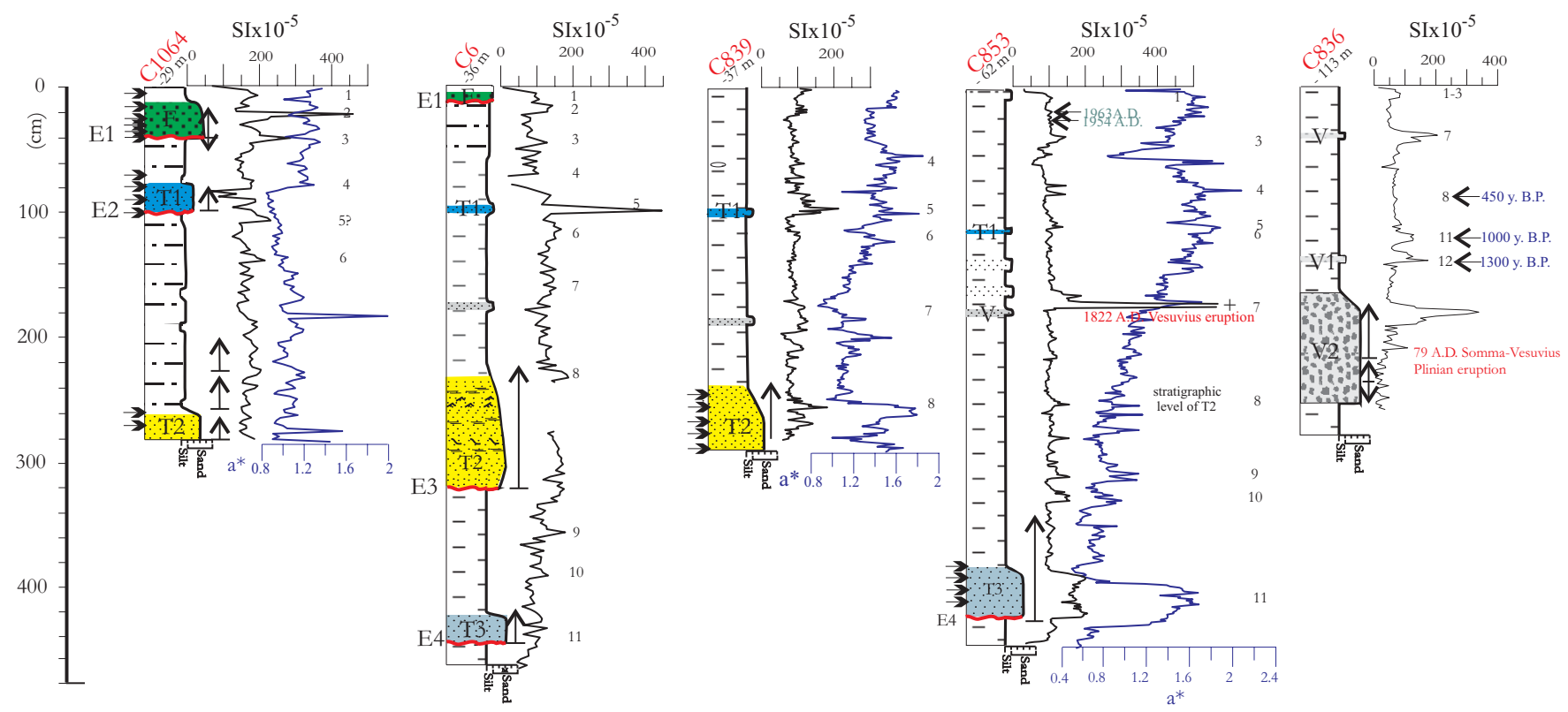

Legend

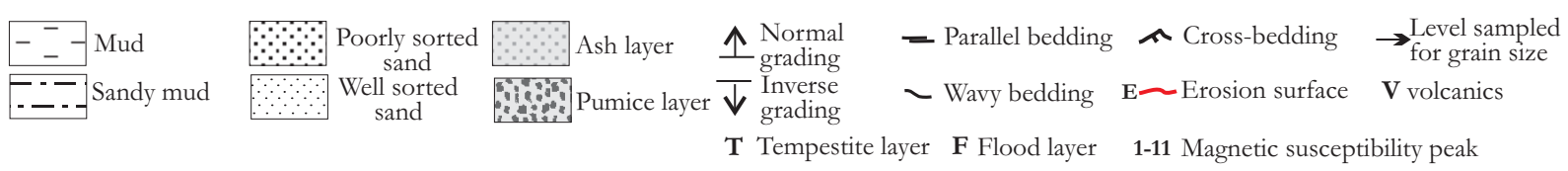

Fig. 2. Core $\operatorname{logs}$ and correlation of event beds based on magnetic susceptibility (m.s.), chromaticity (a*) and lithology. 1-12 are the magnetic susceptibility and parameter $\mathrm{a}^{*}$ chromaticity peaks that lead to the correlation of $\mathrm{F}$ and $\mathrm{T}$ layers among cores. Arrows indicate the stratigraphic position of grain size analysis. Magnetic susceptibility measurements are expressed in S.I. units (Sommerfeld International System). Dating are from Iorio et al. (2004) and Budillon et al. (2005). 


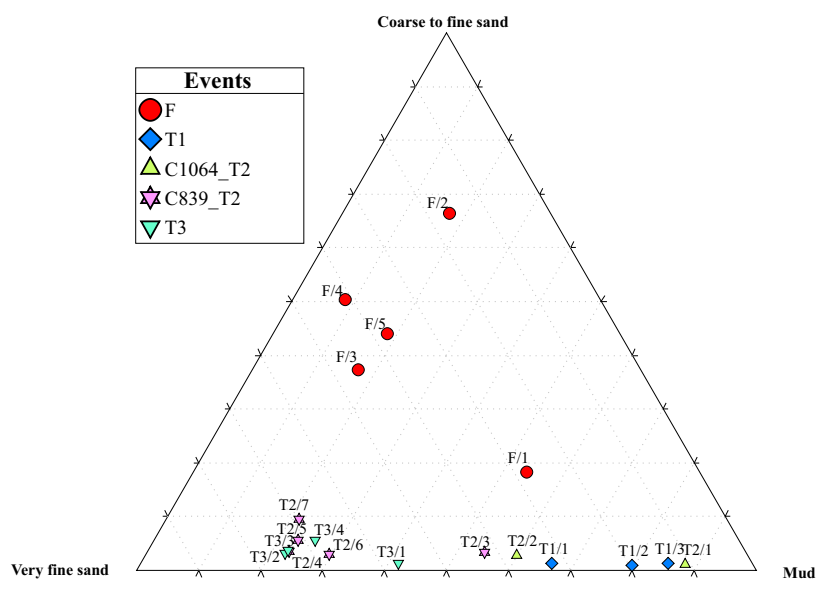

Fig. 3. Results of grain size analysis on $\mathrm{T}$ and $\mathrm{F}$ sandy layers of cores C1064, C853, C839 and C6 are plotted on a modified Shepard (1954) diagram. The grain size classes represented at triangle vertex are from Wentworth (1922) scale as follows: coarse to fine sand (500 microns $>$ grain size $>125$ microns), very fine sand (125 microns $>$ grain size $>63$ microns $)$, mud $=$ (grain size $<63$ microns).

have been supported by visual and mathematical comparison of petrophysical parameters and similar trends according to the litho-stratigraphy (Fig. 2). The magnetic susceptibility (m.s.) parameter is related to the ferromagnetic mineral content in sediment, while the chromaticity parameter $\left(\mathrm{a}^{*}\right)$ is thought to be related, among other factors, to the grain size of the deposits (Nagao and Nakashima, 1992), and thus is useful for univocally correlating sandy layers. In particular, the identification of m.s. peaks $4,5,8$, and 6 leads to the correlation of TI and T2 sandy layers in cores C839 and C853, while $11 \mathrm{~m} . s$. peak recognition and lithostratigraphic consistency lead to correlate T3 sandy layer in cores C6 and C853; on the contrary, the correlation of peak 5, identified in core C1064, remains uncertain across the others (Fig. 2). The uppermost sandy layer $\mathrm{F}$ has been related to the flood event of the 1954 A.D. of the Bonea Stream, that produced a poorly sorted coarse grained sandy layer $20 \mathrm{~cm}$ thick at a distance of $2.6 \mathrm{~km}$ from the stream mouth (Budillon et al., 2005; Violante and Budillon, 2004). In this case a hyperpycnal flow, gave rise to the flood deposit $(\mathrm{F})$ in the mid-shelf environment. The sharp based sandy layers below the Bonea stream flood were attributed to major sea-storm events on the basis of their lithologic features and lateral continuity (Budillon et al., 2005). The event beds identified in cores C1064, C6, C839 and C853 were calibrated by correlating petrophysical peak values to a dated core $(\mathrm{C} 836)$, by ${ }^{210} \mathrm{~Pb}$ and ${ }^{137} \mathrm{Cs}$ geochronology and by the stratigraphic position of the 1822 A.D. Vesuvius tephra. All of the information collected lead to constrain these events to the last 1000 years, and in particular T1 as being deposited in the 19th century, T2 in the 16th century and T3 in the 11th century (Iorio et al., 2004; Budillon et al., 2005).

\subsection{Grain size, textures and grain fabric of sandy layers}

The grain fabric of tempestites is generally related to the different phases of the underflow motion (Dott and Bourgeois, 1982; Niederoda et al., 1989) which may produce a normal grading, a parallel and a wave layering of sand. A remarkable difference was observed among textures and grain fabric of sand layers even if occurring in the same core (C1064, Fig. 2; Budillon et al., 2005; Violante and Budillon, 2004). A modified Shepard (1954) diagram was used to plot grain size results (Fig. 3). Instead of the classic vertex represented by clay-silt-sand fractions (Shepard, 1954), sand, very fine sand, and mud were positioned at the triangle vertex in order to adjust the diagram to the real lithology of sandy layers. As shown in Fig. 3, samples of F deposit fall in the central - left side of the triangle, testifying a poor sorting of grains and are set apart from the position of other samples. On the contrary samples from $\mathrm{T}$ deposits are concentrated on the left side of the diagram, indicating a good sorting of grains and a prevalence of very fine sandy fraction.

All $\mathrm{T}$ layers then pass gradually into mud, which represents the waning phase of the underflow motion induced by a sea-storm (Wright et al., 2001). Subsequently a cup of hemipelagic mud seals tempestite deposits and point to the inter-storm time span. Nevertheless, only the T2 layer in core C6 shows the theoretical grain fabric of tempestites, while other $\mathrm{T}$ layers do not, except for a general fining up trend. This point is not casual but could depend on the fact that the T2 layer in the C6 core is the thickest layer (about $80 \mathrm{~cm}$ ) among tempestite deposits found in studied cores. As described in Keen et al. (2004), benthic organisms, whose activity is higher in areas with low sedimentation rates, may burrow the first $10 \mathrm{~cm}$ of seafloor sediment in one year of time, and then quickly destroy the original sedimentary structures. If the tempestite sandy layer is thick enough and the rate of burial is high, it has more possibilities to maintain its original grain fabric (Wheathcroft and Drake, 2003), as likely happened at level $\mathrm{T} 2$ in core $\mathrm{C} 6$.

\subsection{Structures of the hyperpycnal flow versus tempestite layers}

Lithostratigraphic observations on $\mathrm{F}$ and $\mathrm{T}$ layers evidenced the peculiar structure of the hyperpycnal flow generated by the 1954 A.D. Bonea stream flood (Esposito et al., 2004b; Budillon et al., 2005). The inversely graded sandy mud interval below E1 (Fig. 2) may be accounted for by the increasing rate of discharge at the river mouth (Mulder et al., 2003) due to the persistent heavy rainfall; E1 erosion surface, and the overlaying coarse bed rich in vegetal debris (Fig. 4), could be the consequence of river wave flood due to dams break down and subsequent overcharged flux to the coast (Esposito et al., 2004b). In that case the erosion surface E1 would have the significance of the "intrasequence erosional contact" of Mulder et al. (2003). The erosive potential of the hyperpycnal flow and its thickness rapidly decreased seaward, since only a thin sandy layer overlays the E1 surface in C6 core 

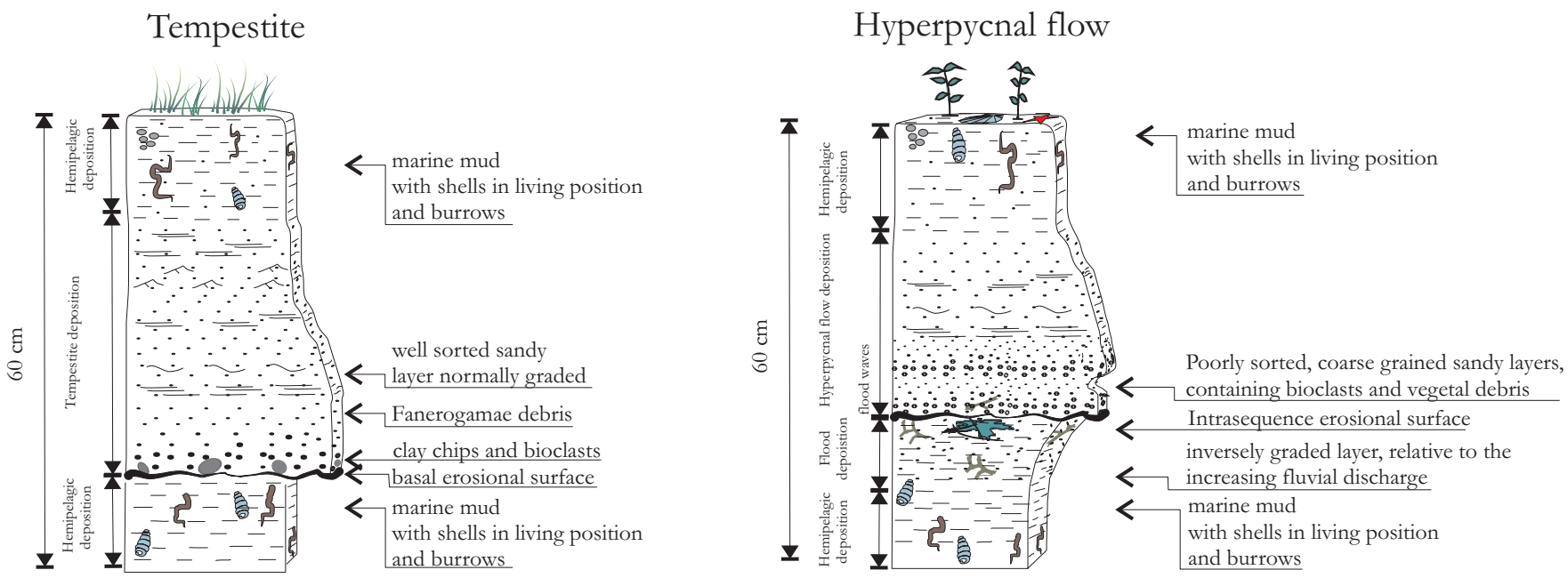

Fig. 4. Schematic stratigraphic representation of hyperpycnal flow and tempestite deposits as recognizable by marine sediment cores observations.

and no coarse bed is found at the same stratigraphic level in the C853 core (Fig. 2). On the contrary, T sandy layers cut invariably into marine mud. The coarse sand immediately above the basal erosional surfaces often includes clay chips, thus testifying the erosive potential of tempestite underflow currents. Sand deposit is richer in benthic foraminifers and in bioclasts than in woods and vegetal debris, and is gradually replaced upward by the mud. The mud interval containing gasteropods in living position (in this case Turritellae shells) and pervaded by a dense net of burrows can be interpreted as being the hemipelagic mud, thus not pertaining to the tempestite deposition. Also, in the Mediterranean Sea sedimentcharged flows of sea-storm origin may normally contain bioclasts and Posidonia oceanica debris (T2 in core C6, Fig. 4), because they winnow and rework the shallow marine sediment over a large portion of coastal areas.

\subsection{Chronologic constrain of tempestites}

An attribution of T1, T2 and T3 layers to the 11th, 16th, 19th centuries respectively was attempted in Budillon et al. (2005), based on correlations with a dated core (C836), tephra-stratigraphy and geochronology (Fig. 2). The critical analysis of inventories, here reported, resulted effectively with three major events that occurred in 1544, 1774 and 1879 A.D. and among these, the first sea-storm hit the coast in the surrounding of Capo D'Orso in particular. A good correlation between our deductions and reported storm events could lead to the attribution of the T2 sandy layer (16th century) to the 1544 A.D. event and the T1 (19th century) to the 1879 A.D. event. The T2 tempestite extends mainly in the proximity of Capo d'Orso, as revealed by seismic lines (Budillon et al., 2005; Violante and Budillon, 2004), thus reinforcing a possible genetic link between this layer and the sea-storm of the 1544 A.D. The 1774 A.D. event seems to lack in cores if we consider this sea-storm as heavy as the T2 and T3 events. Actually, very thin sand layers and sand patches are present at various depths in cores (Fig. 2) but without any other constrain (texture, erosional basal contact...) it would be inappropriate to try to correlate discontinuous sandy levels to a sea-storm event, even if the stratigraphic position would allow it.

\subsection{Tempestite layers from VHR seismic profiles}

Very high resolution chirp profiles allowed to identify reflectors bouncing back from tempestite sandy layers, occurring in the stratigraphic record of the Salerno shelf (Fig. 5). Seismic reflectors corresponding to tempestites show high variable amplitude and even some interruptions at places; nevertheless they are recognizable throughout a wide sector of the northern Salerno shelf. They develop between 20 and $60 \mathrm{~m}$ of water depth and show a sharp termination seaward, due to the thinning of sand layers below the instrument resolution (about $30 \mathrm{~cm}$ ). The lateral distribution of T reflectors allowed to figure out the large amount of sand mobilized and transported down slope during a major sea-storm, when the conditions to develop down-welling currents are achieved (Myrow and Southard, 1996). The depth of penetration of cores let us gauge the seismic record for the first 6-10 msec (two way travel time); however very similar reflections to the ones corresponding to $\mathrm{T}$ layers in cores are present in the seismic record even below (Fig. 5). In particular two tempestitelike reflections develop below the T3 reflector and above the Vesuvius pumice deposit related to the 79 A.D. plinian eruption (Buccheri et al., 2002) and two others develop below it. This could mean that the same style of deposition has been running since $3 \mathrm{kyr}$ B.P. Tempestites are mostly represented in the seismic record of the mid-shelf because they develop as fine grained sand (Fig. 3) in the shelf depocentres, they are visible by VHR seismic investigations and they are easily sampled by gravity coring. On the contrary hyperpycnal flow 

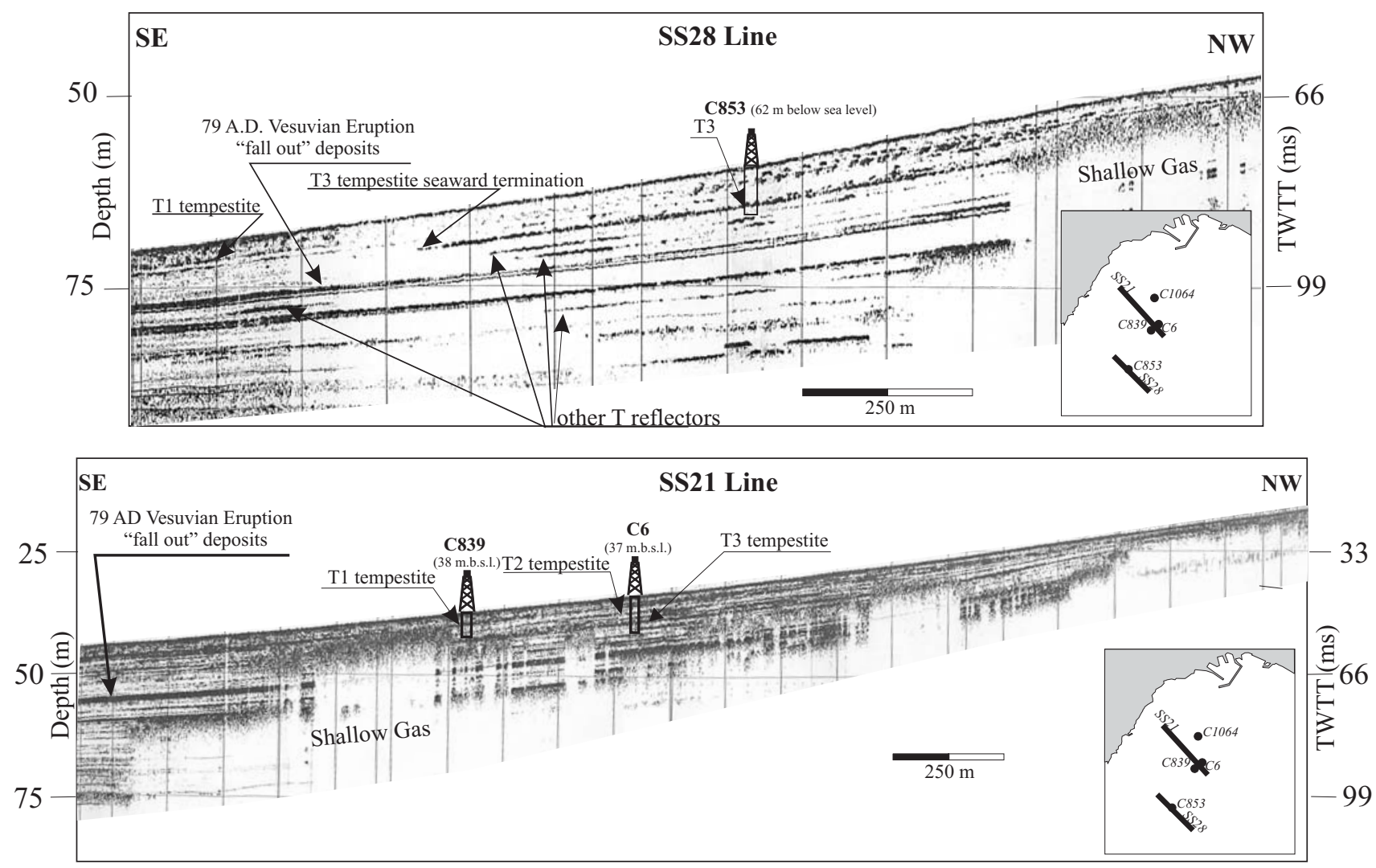

Fig. 5. Very high resolution seismic lines (Sub-bottom Chirp) shot normally to the Bonea stream coast show the extention of tempestite deposits..

deposits, mostly coarse grained, in particular the one from the Bonea stream, are confined to the inner shelf (Budillon et al., 2005), where sandy fractions prevail. These factors make it more difficult to identify HFD in the stratigraphic record of the inner shelf by means of VHR seismic survey due to the acoustic masking potential of sand. Furthermore, as demonstrated by several authors, event beds in the shallow marine environment undergo resuspention and winnowing due to the reworking action of high amplitude waves during "dry storms" (Weathrcroft and Drake, 2003; Guillen et al., 2005)

\section{Conclusions}

Both hyperpycnal flows from flood-prone stream and tempestites occurring as sand layers in the stratigraphic record of shelf areas are event beds regarded as a proxy of past storminess. A typical structure of a proximal hyperpycnal flow and of a tempestite has been described in order to facilitate their identification by means of standard geological marine surveying (gravity cores and seismic investigations). The case study of the Salerno Bay shelf record lead us to recognize four event beds related to major storms that occurred in the area during the last $1 \mathrm{kyr}$. The most recent bed (F) was related to the extreme flood event that hit the Salerno region in 1954 A.D. (Budillon et al., 2005; Violante et al., 2004). The two event beds below have been here interpreted as being possibly generated by two major sea-storms occurred in 1544 and 1879 A.D. respectively, while the oldest tempestite remains with an unknown attribution. It is likely that other tempestite event beds occur in the stratigraphic record of the Salerno shelf as it emerges by seismic lines interpretation. At least two other major events may have deposited a thick sandy layer (thicker than the threshold of the instrument resolution, which is about $30 \mathrm{~cm}$ ) above 79 A.D. Vesuvius tephra and below the T3 tempestite, and two more major events could have acted between the 79 A.D. and $3.3 \mathrm{kyr}$ (Conforti, 2003). All these elements match well with the hypothesis of a climatic trend degradation inferred for the last $3 \mathrm{kyr}$ in the area and depicted by archaeological, biostratigraphic and lithostratigraphic data (Allocca et al., 2001; Buccheri et al., 2002; Iorio et al., 2004).

The reconstruction of remarkable events on land and in the shallow marine sediment record highlights the flood- and sea wave-related hazard and the associated risk to which the Salerno coastal area is exposed, when major storms hit the coast and go so far as to have an impact on the morphology of the shore and of the seabed. 
Acknowledgements. The present research has been developed with the financial support of MIUR in the frame of Cluster 10, Project n. P04 (GeoSed - Geomorfologia e sedimentologia di settori selezionati della piattaforma continentale dell' Italia Meridionale). The authors are grateful to Patricia Sclafani and two anonymous referees for the reviews to the manuscript.

Edited by: L. Ferraris

Reviewed by: anonymous referees

\section{References}

Allocca, F., Amato, V., Coppola, D., Giaccio, B., Ortolani, F., and Pagliuca, S.: Cyclical climatic-environmental variations during the Holocene in Campania and Apulia: geoarcheological and paleoethonological evidences, Mem. Soc. Geol. It. 55, 345-352, 2000

Archivio di Stato di Salerno, (AS SA), Intendenza, 1800-1899.

Archivio di Stato di Salerno, (AS SA), Prefettura 1834-1924.

Archivio di Stato di Salerno, (AS SA), Protocolli notarili 15001798.

Brancaccio, L., Cinque, A., Romano, P., Rosskopf, C., Russo, F., Santo, A., and Santangelo, N.: Geomorphology and neotectonic evolution of a sector of the Tyrrhenian flank of the Southern Apennines (Region of Naples, Italy), Zeit. Geomorph., N.F., Suppl. Bd., 82, 47-58, 1991.

Buccheri, G., Capretto, G., Di Donato, V., Esposito, P., Ferruzza, G., Pescatore, T., Russo Ermolli, E., Senatore, M.R., Sprovieri, M., Bertoldo, M., Carella, D., and Madonna, G.: A high resolution record of the last deglaciation in the southern Tyrrhenian Sea: environmental and climatic evolution, Mar. Geol. 186, 447470, 2002

Budillon, F., Violante, C., Conforti, A., Esposito, E., Insinga, D., Iorio, M., and Porfido, S.: Event beds in the recent prodelta stratigraphic record of the small flood-prone Bonea stream (Amalfi Coast, Southern Italy), in: Mar. Geol., special issue, edited by: Syvitski, J. P. M. and Trincardi, F., in press, 2005.

Camera, M.: Istoria della città e costiera di Amalfi, 1836, Ristampa anastatica, Sala Bolognese, 1985.

Cocco, E., de Magistris, M. A., Efaicchio, M. T., and Boscaino, F.: Geoenvironmental features of the Sele river littoral plain (Gulf of Salerno, Southern Italy), Boll. Ocean. Teor. Appl., 10, 235-246, 1992.

Conforti, A.: Stratigrafia integrata della sequenza TardoQuaternaria del settore settentrionale del Golfo di Salerno e di quello meridionale del Golfo di Napoli, Unpublished PhD Thesis, Università Federico II di Napoli, pp. 144, 2003.

Dott, R. H. and Bourgeois, J.: Hummocky stratification: significance of its variable bedding sequence, Geological Society of American Bulletin 93, 663-680, 1982.

Duke, W.: Hummocky cross-stratification, tropical hurricanes, and intense winter storms, Sedimentology 32, 167-194, 1985.

Esposito, E., Porfido, S., Violante, C., Biscarini, C., Alaia, F., and Esposito, G.: Water events and historical flood recurrences in the Vietri sul Mare coastal area (Costiera Amalfitana, southern Italy), Proceedings of the UNESCO/IAHS/IWHA symposium on "The Basis of Civilization - Water Science?", Rome, IAHS Publ. 286, 2004a.

Esposito, E., Porfido, S., and Violante, C. (Eds.): Il nubifragio dell'ottobre 1954 a Vietri sul Mare, Costa di Amalfi Salerno, CNR GNDCI, Pubbl n. 2870, pp. 381, 2004b.
Fan, S., Swiff, D. J. P., Traykovsky, P., Bentley, S., Borgeld, J. C., Reed C. W., and Niedoroda, A. W.: River flooding, storm resuspension and event stratigraphy on the northern California shelf: observation compared with simulation, Mar. Geol. 210, 17-41, 2004.

Froese, D. G., Smith, D. G., Westgate, J. A., Ager, T. A., Preece, S. J., Sandhu, A., Enkin, R. J., and Weber, F.: Recurring Middle Pleistocene outburst floods in east-central Alaska, Quaternary Research, 60, 50-62, 2003.

Geyer, W. R., Hillb, P. S., and Kinekec, G. C.: The transport, transformation and dispersal of sediment by buoyant coastal flows, Continental Shelf Research, 24, 927-949, 2004.

Greco, M.: Cronaca di Salerno (1709-1787), Ristampa di un manoscritto della fine del XVIII sec. A cura di E. Pettine, Palladio, Arti grafiche, Salerno, 1985.

Guillen, J., Bourrin, F., Buscail, R., Palanques, A., Puig, P., and Durrieu de Madron, X.: Comparison of sediment dynamics during "wet" and "dry" storm events on the Tet Prodelta, Geophysical Research Abstracts, Vol. 7, 07174, European Geosciences Union, 2005.

Iorio, M., Sagnotti, L., Angelino, A., Budillon, F., D’Argenio, B., Turell Dinares, J., Macrì, P., and Marsella, E.: High-resolution petrophysical and paleomagnetic study of late-Holocene shelf sediments, Salerno Gulf, Tyrrhenian Sea, Holocene, 14 (3), 433 442, 2004.

Jansa, A.: Some requirements for severe storm forecasting in the Mediterranean, in: Mediterranean Storms, edited by: Mugnai, A., Guzzetti, F., Roth, G., 2nd EGS Plinius conference on Mediterranean Storm, Siena, Italy, Proceedings, 141-153, 2000.

Keen, T. R., Bentley, S. J., Chad Vaughan, W., and Blain, C. A.: The generation and preservation of multiple hurricane beds in the northern Gulf of Mexico, Mar. Geol., 210, 79-105, 2004.

Morton, R. A.: Formation of storm deposit by wind-forced currents in the Gulf of Mexico and the North Sea, in: Holocene Marine Sedimentation in the North Sea Basin, edited by: Nio, Shuttenhelm, R. T. E., van Weering, Tj. C. E., Special Publication International Association of Sedimentologists, 5, 385-396, 1981.

Mulder, T. and Syvitski, J. P. M.: Turbidity currents generated at river mouths during exceptional discharges to the world oceans, J. Geol., 103, 285-299, 1995.

Mudler, T., Syvitski, J. P. M., and Skene, K. I.: Modelling of erosion and deposition by turbidity currents generated at river mouths, J. Sediment. Res., 68 (1), 124-137, 1998.

Mutti, E., Tinterri, R., Benevelli, G., di Biase, D., and Capanna, G.: Deltaic, mixed and turbidite sedimentation of ancient foreland basins, Marine and Petroleum Geology, 20 (6-8), 733-755, 2003.

Myrow, P. and Southard, J. B.: Tempestite Deposition, J. Sediment. Res., 66 (5), 875-887, 1996.

Nagao, S. and Nakashima, S.: The factors controlling vertical colour variations of North Atlantic Madeira Abyssal Plain sediments, Mar. Geol., 109, 83-94, 1992.

Niedoroda, A. W., Swift, D. J. P., and Thorne, J. A..: Modelling shelf storm beds: control of bed thickness and bedding sequence, in: Shelf sandstone, shelf depositional sequence and petroleum accumulation: a symposium, SEPM, Tulsa, Oklahoma, 15-39, 1989.

Ramos, M. C.: Changes in rainfall distribution patterns over the year in the Mediterranean climate, in: Mediterranean Storm 2000, edited by: Mugnai, A., Guzzetti, F., Roth, G., Proceedings of the 2nd Plinius Conference, Siena, Italy, 323-335, 2000a. 
Ramos, M. C.: Differences of the characteristics of the storms recorded along the year in a Mediterranean climate, in: Mediterranean Storm 2000, edited by: Mugnai, A., Guzzetti, F., Roth, G., Proceedings of the 2nd Plinius Conference, Siena, Italy , 331340, 2000b.

Shepard, F. P.: Nomenclature based on sand-silt-clay ratios, J. Sedimentary Petrology, 24, 3, 151-158, 1954.

Siccardi, F.: Rainstorm hazards and related disasters in the Western Mediterranean region, Remote Sensing Reviews, 14, 5-21, 1996.

Snedden, J. W. and Nummendal, D.: Origin and geometry of stormdeposited sand beds in modern sediments of the Texas continental shelf, in: Shelf sand and sandstone bodies, edited by: Swift, D. J. P., Oertel, G. F., Tilmann, R. W., and Thorne, J. A., Spec. Publication-International Association of Sedimentologists, 14, Blackwell Scientific, Boston, Ma, 283-308, 1991.
Violante, C. and Budillon, F.: L'evento eccezionale dell'ottobre 1954 nell'offshore di Salerno: portata solida e trasporto eccezionale di sedimento nelle adiacenti aree marine, in: Il nubifragio dell'ottobre 1954 a Vietri sul Mare, Costa di Amalfi Salerno, edited by: Esposito, E., Porfido, S., and Violante, C., CNR GNDCI, Pubbl n. 2870, 58-66, 2004.

Wentworth, C. K.: A scale of grade and class terms for clastic sediments, J. Geology, 30, 377-392, 1922.

Wheatcroft, R. A. and Drake, D. E.: Post-depositional alteration and preservation of sedimentary event layers on continental margins, I. The role of episodic sedimentation, Mar. Geol., 199, 123-137, 2003.

Wright, L. D., Friedrichs, C. T., Kim, S. C., and Scully, M. E.: Effects of ambient currents and waves on gravity-driven sediment transport on continental shelves, Mar. Geol., 175, 25-45, 2001. 